\title{
EVALUATION OF SERVICE QUALITY IN NURSING AND PATIENT SATISFACTION: PERCEPTION OF PATIENTS AND STUDENT NURSES
}

\author{
E.T. Jagoda ${ }^{1 *}$, E.A.K.K. Edirisinghe ${ }^{2} \&$ M.K.D.L. Meegoda ${ }^{3}$ \\ ${ }^{1}$ Collage of Nursing, Galle, Sri Lanka \\ ${ }^{2}$ International Institute of Health Sciences, Sri Lanka \\ ${ }^{3}$ University of Sri Jayewardenepura, Sri Lanka
}

\begin{abstract}
Evaluation of service quality and patient satisfaction should be an ongoing process for improving the quality of patient care. Quality of caring behaviour significantly impact on patient satisfaction. The aim of this study was to determine the service quality of nursing care through patients' and student nurses' perception on nurses' caring behaviours and patient satisfaction. This descriptive study was conducted in 2018 in the surgical and medical wards of a leading hospital in Southern Province, Sri Lanka. The study population was patients $(\mathrm{N}=300)$ and 3rd-year student nurses $(\mathrm{N}=115)$. Random sampling technique was used. Validated and modified 5 point-Likert scales of "perception of caring-behaviors" and "SERVQULAL" were employed. Jean Watson's theory of human caring was incorporated in the study. Descriptive analysis, Pearson's correlation, and regression analysis were performed. The mean was computed (1-5) and higher score reflected positive perception. Patients' perception was above average level on caring behaviour (4.07 \pm 0.54$)$ and satisfaction $(3.21 \pm 0.64)$. There was a strong correlation between perceived caring behaviour and patient satisfaction (Pearson Correlation 0.65). Findings revealed that patients rated higher in terms of caring behavior compared to the ratings of student nurses $(3.47 \pm 0.65)$ and there was a significance difference between two groups $(0.03<0.05)$. According to regression analysis between independent (caring behaviour) and dependent variable (satisfaction), R2 was 0.44 . Jean Watson's theory of care, bedside handover, information provision to the patients, empathetic approach and patients' awareness on ideal nursing care are recommended to further increase quality and satisfaction. Area of culturally appropriate therapeutic touch is recommended for future research.
\end{abstract}

Keywords: quality nursing care, patient satisfaction, caring behaviors.

\section{Introduction}

The main aspect of nursing is caring. Quality of caring need to be maintained throughout the provision of nursing care. Evaluation of service quality and patient satisfaction should be an ongoing process for improving the quality of patient care. (Mohebifar et al., 2016). Researchers around the world found association between patient satisfaction and quality of patient care thus patient satisfaction is a key feature evaluating quality of nursing care (Feuerbach, 2007; Bicknell, 2008; Wagner and Bear, 2008; Reck, 2010; Gares, 2011; Azizi-fini et al., 2012; Milutinovic et al., 2012; Peprah and Atarah, 2014; Chan et al., 2015). Reduction of patient satisfaction is a result of nurses who do not consider the quality of caring (Aiken et al., 2018). The healthcare managers in government hospitals of some developing countries, including Sri Lanka, enormously ignore the patients' perceptions to measure quality of health care and there were only few studies published in relation to assess patient's satisfaction in Sri Lanka (Senarat and Gunawardena, 2011).

Service quality with proper caring behaviour can significantly impact on patient satisfaction(Gares, 2011; Bucco, 2015). Greenhalgh, Vanhanen, \& Kygas (1998) defined the patients' perceptions of nurse caring behaviors as "patients' perceptions of nurses' acts, conduct, and mannerisms that convey concern, safety, and attention to the patient". The relationship exists between the patient perception of nurses' caring behaviors and patients' satisfaction (Bucco, 2015). Furthermore, there are different perspectives on caring behaviour among different countries (Weathers et al., 2012). Patients of the general wards were satisfied with nurses' technical and 
professional care and their quick delivery of nursing care; while they were dissatisfied with patient education, treatment plan and pain management and inadequate response to patients' needs (Mien Li GOH and Vehviläinen-julkunen, 2016). For tailoring nursing interventions or caring behaviors of nurses to patients' requirements, it is essential to understand patients' perception (Modic et al., 2016).

Student nurses are exposed to hospital-based training at teaching hospitals (Mukumbang and Adejumo, 2014). Demonstration of caring behaviors by clinical nurses can be a key factor in influencing the learners' perception of the importance of caring behaviors in the profession (Atwood, 2017). A research conducted in Asian countries has revealed that overall patient satisfaction levels were high in Asian countries including Sri Lanka (Dayasiri and Lekamge, 2010). That study was conducted in Western Provinces in Sri Lanka. However, it was hard to find studies on nurses caring behaviours and patient satisfaction from the southern province of Sri Lanka. Patient satisfaction is a complex process having many contributory factors (Gares, 2011). Few studies were conducted in medical-surgical units to identify patient satisfaction, although surgical and medical units are common caring sites of the hospital serving for a large population (Youssef et al., 2013). It is worth to study patient satisfaction with nursing care through various type of stakeholders and in various settings and cultures (Mukumbang and Adejumo, 2014). Objective of this study was to assess the service quality of nursing care through perception of patients' and student nurses', and to assess patient satisfaction with nursing care in surgical - medical units of a leading hospital in Southern Province, Sri Lanka.

\section{Methodology}

A descriptive cross-sectional study was conducted in 2018. A leading hospital in Southern Province and attached nursing education institutes, a Collage of Nursing Galle and Faculty of Allied Health were chosen as the study settings.

Population of the study was the patients of the surgical - medical units and third year student nurses. The sample size was calculated with openEpi software (a 95\% confidence interval and a 5\% significance level). Random sampling technique was performed. According to the number of beds in surgical and medical units of the hospital, 321 patients were invited (responded rate $=98 \%$ ). Inclusion criteria was $18-60$ year old patients who were in surgical or medical wards, staying at the hospital more than 72 hours. The patients who were semiconscious, unconscious, terminally ill, psychiatric, critically ill and weak to talk with the investigator were excluded. Randomly selected 103 students from the college of nursing and 21 students from the university proportionately were invited to participate in the study (responded rate $=92.7 \%$ ). The student nurses who were on leave at the time of data collection were excluded.

Jean Watson is one of the innovative in the caring theories of nursing (Wadsworth, 2012; Bucco, 2015). Watson's theory of human caring, was a theoretical framework for this study, describes components of caring as ten carative factors (Bagnall, 2017). Based on Watson's theory, many of the instruments were developed to study nurse caring behaviours such as Caring Behaviors Inventory (CBI) by Wolf et al. (Bucco, 2015).

Modified questionnaire (Perception on Caring Behaviour -PCB) was prepared by the investigator based on Watson's theory of human caring, Caring Behaviors Inventory-24 (CBI-24) by Wu, Larrabee, \& Putnam (2006) and Patient Satisfaction Instrument (PSI) by Hinshaw \& Atwood (1982). A modified Service Quality (SERVQUAL) instrument was adapted to collect information on patient satisfaction on caring. Face validity was achieved with the discussion of pilot group sample. Content validity was assured by a nurse educator and researcher and a medical administrator. 
Administrative approval received from the relevant institutions and ethical approval received from Ethical Review Committee of Faculty of Medicine, University of Ruhuna. Written consent was obtained from the participants.

\section{Data analysis}

Quantitative data were analyzed using Statistical Package for the Social Sciences (SPSS), version 22 software. Prior to analysis, data were prepared by means of checking hard copies against entered values and daily transfer of information into SPSS spreadsheet and piloting. Descriptive statistics were computed to study about PCB and modified SERVEQUAL in the form of frequencies, means, standard deviations, and percentages. Pearson's correlation, independent t-test, and regression analysis were used to analyze relationships.

\section{Results}

PCB (patient version), PCB (student version) and modified SERVQUAL reflected an excellent level of reliability (Cronbach's alpha $=0.88,0.931$ and 0.94 , respectively) of this study.

Table 1 represents the demographic data of the patients and the student nurses.

Table 1: Demographic data of the patients and students

\begin{tabular}{|c|c|c|c|}
\hline Variables & Categories & Frequency & Percentage $(\%)$ \\
\hline \multicolumn{4}{|l|}{ Demographic data of the patients } \\
\hline \multirow[t]{2}{*}{ Unit types } & Medical & 132 & 44.0 \\
\hline & Surgical & 168 & 56 \\
\hline \multirow[t]{4}{*}{ Age (years) } & $18-30$ & 45 & 15 \\
\hline & $31-40$ & 55 & 18.3 \\
\hline & $41-50$ & 70 & 23.3 \\
\hline & $51-60$ & 130 & 43.3 \\
\hline \multirow[t]{5}{*}{ Gender } & Male & 133 & 44.3 \\
\hline & Female & 167 & 55.7 \\
\hline & $2-3$ & 140 & 46.7 \\
\hline & $4-5$ & 44 & \\
\hline & $>5$ & 64 & 21.3 \\
\hline \multirow[t]{4}{*}{ Length of hospitalizations (days) } & 3 & 67 & 22.3 \\
\hline & $4-7$ & 132 & 44 \\
\hline & $8-14$ & 63 & 21 \\
\hline & $>14$ & 38 & 12.7 \\
\hline \multicolumn{4}{|c|}{ Demographic data of the student nurses } \\
\hline \multirow[t]{2}{*}{ Education } & Degree & 19 & 16.5 \\
\hline & Diploma & 96 & 83.5 \\
\hline \multirow[t]{2}{*}{ Gender } & Male & 15 & 13.04 \\
\hline & Female & 100 & 86.95 \\
\hline
\end{tabular}

Nurse caring behaviors, as perceived by the patient, were measured using the PCB. The scale was computed by taking the mean score (1-5) and higher score reflected greater nurse caring behaviors as rated by the patients. 
The mean perception on overall caring was 4.07 \pm 0.54 . The table 2 shows descriptive Statistics for each variable of PCB. According to the table 2, all the caring behavior variables were perceived greatly by the patients above average level.

Table 2: Descriptive Statistics for each variable of $P C B$

\begin{tabular}{|c|c|c|c|c|c|c|c|c|}
\hline & $\mathrm{N}$ & Range & Minimum & Maximum & Mean & & SD & Variance \\
\hline & Statistic & Statistic & Statistic & Statistic & Statistic & Std. Error & Statistic & Statistic \\
\hline Professionalism & 300 & 2.57 & 2.43 & 5.00 & 4.0394 & .03799 & .65806 & .433 \\
\hline Assurance & 300 & 2.75 & 2.25 & 5.00 & 4.1305 & .03667 & .63518 & .403 \\
\hline Relationship & 300 & 2.75 & 2.25 & 5.00 & 4.1204 & .03465 & .60020 & .360 \\
\hline Knowledge \& skill & 300 & 3.40 & 1.60 & 5.00 & 3.9529 & .04206 & .72842 & .531 \\
\hline Overall PCB & 300 & 2.29 & 2.71 & 5.00 & 4.0706 & .03141 & .54398 & .296 \\
\hline
\end{tabular}

Table 3 represents the mean values of items in professionalism variable. Nurses conversed in a polite and kind manner always according to $68.7 \%$ of patients. $41.35 \%$ patients said that nurses never provide information prior to investigations.

Table3: Patients' Perception of Professionalism (obtained using PCB)

\begin{tabular}{llllll}
\hline Items of Professionalism & $\mathrm{N}$ & \multicolumn{3}{c}{ Min. Max. Mean SD } \\
\hline The nurses respect my opinions and/or suggestions on nursing care & 300 & 1 & 5 & 4.51 & .934 \\
\hline The nurses converse in a polite and kind manner & 300 & 1 & 5 & 4.61 & .673 \\
\hline $\begin{array}{l}\text { The nurses observes/assess me frequently } \\
\text { The nurses provide adequate information prior to investigations } \\
\text { (e.g. before drawing blood or before sending to scan) }\end{array}$ & 298 & 1 & 5 & 4.34 & .886 \\
\hline The nurses evaluate care outcome of the patient & 291 & 1 & 5 & 3.08 & 1.826 \\
\hline The nurses consider my environment & 296 & 1 & 5 & 4.05 & 1.166 \\
\hline The nurses respect my family members and their opinions & 298 & 1 & 5 & 3.88 & 1.184 \\
\hline
\end{tabular}

Table 4 shows the mean values of items in assurance variable. $79 \%$ of the patients stated that they always receive care/ medication on time. $26.3 \%$ patients said that nurses never encourage the patients to ask questions. Although $60 \%$ mentioned that nurses were quick to react to their requests, $16 \%$ patients perceived that nurses never or occasionally understand their feelings.

Table 4: Patients' perception on assurance for received care (from PCB)

\begin{tabular}{llllll}
\hline Items of assurance & $\mathrm{N}$ & Min. & Max. & Mean & SD \\
\hline The nurses are quick to react to my requests & 300 & 2 & 5 & 4.49 & .706 \\
\hline The nurses spent enough time to answer my questions & 295 & 1 & 5 & 3.94 & .981 \\
\hline The nurses encourage me to ask questions/seek clarification & 258 & 1 & 5 & 3.15 & 1.663 \\
\hline The nurses understand my feeling & 287 & 1 & 5 & 3.69 & 1.303 \\
\hline The nurses take measures to ensure my safety & 300 & 1 & 5 & 4.05 & 1.196 \\
\hline When there are nurses around, I always feel well and secure & 292 & 2 & 5 & 4.58 & .571 \\
\hline The nurses provide nursing care and medication on time & 300 & 1 & 5 & 4.70 & .714 \\
\hline The nurses assist me in relieving pain & 298 & 1 & 5 & 4.27 & 1.023 \\
\hline
\end{tabular}

Table 5 is the mean values of items in trusting interpersonal relationship. $62.3 \%$ of the patients indicated that nurses were always friendly. However, only $32 \%$ nurses practiced therapeutic touch (holding or touching 
patient's hand/ shoulder to reduce fear) while caring or communication. $20 \%$ nurses never asked many questions to clarify patients' needs while only $27 \%$ practicing it always.

Table 5: Patients' perception on trusting interpersonal relationship

\begin{tabular}{|c|c|c|c|c|c|}
\hline Items of trusting interpersonal relationship & $\mathrm{N}$ & Minimum & Maximum & Mean & SD \\
\hline The nurses are friendly towards me & 300 & 1 & 5 & 4.39 & .967 \\
\hline The nurses ask many questions to clarify my needs & 298 & 1 & 5 & 3.52 & 1.427 \\
\hline $\begin{array}{l}\text { When I need someone to share my feelings related to } \\
\text { disease/ hospitalization, I can approach the nurses }\end{array}$ & 298 & 1 & 5 & 4.34 & .905 \\
\hline $\begin{array}{l}\text { When providing care or during communication, the nurses } \\
\text { hold or touch my hand/ shoulder to reduce my fear }\end{array}$ & 282 & 1 & 5 & 3.65 & 1.437 \\
\hline The nurses get angry with me & 300 & 1 & 5 & 4.43 & 1.193 \\
\hline $\begin{array}{l}\text { The nurses always take necessary actions to help me when I } \\
\text { have a problem or need }\end{array}$ & 296 & 2 & 5 & 4.45 & .636 \\
\hline $\begin{array}{l}\text { The nurses show that they are always around the patient } \\
\text { even in night shifts }\end{array}$ & 297 & 1 & 5 & 4.36 & .855 \\
\hline $\begin{array}{l}\text { Nurses provide adequate answers to questions from family } \\
\text { members }\end{array}$ & 300 & 1 & 5 & 3.80 & 1.233 \\
\hline
\end{tabular}

Table 6 illustrates the mean values of items in Knowledge and skill.47.3\% expressed that nurses never provide examination results. Moreover, $22.4 \%$ stated, nurses never give enough information regarding prevention, diet, and discharge plan.

Table 6: Patients' perception on knowledge and skill (from PCB)

\begin{tabular}{llllll}
\hline Items of knowledge and skill & $\mathrm{N}$ & Min. & Max. & Mean & SD \\
\hline $\begin{array}{l}\text { The nurses inform me correctly about my examination results such as } \\
\text { blood pressure, urine ward test results, blood sugar level, platelet } \\
\text { level, temperature, pulse }\end{array}$ & 298 & 1 & 5 & 2.74 & 1.706 \\
\hline $\begin{array}{l}\text { The nurses provide adequate advice regarding prevention, diet, } \\
\text { discharge plan }\end{array}$ & 294 & 1 & 5 & 3.52 & 1.523 \\
\hline $\begin{array}{l}\text { The nurses explain information I need in a simple manner } \\
\text { The nurses are calm and organized while caring for me }\end{array}$ & 298 & 1 & 5 & 4.45 & .724 \\
\hline The nurses are very active while performing her job & 298 & 1 & 5 & 4.42 & .846 \\
\hline
\end{tabular}

The table 07 shows the results of descriptive analysis of overall satisfaction on each variable. Mean satisfaction with all the variables of SERVQUAL was $3.2 \pm 0.64$

Table 07: Overall satisfaction according to SERVQUAL

\begin{tabular}{lllllll}
\hline & $\mathrm{N}$ & Minimum & Maximum & Mean & \multicolumn{2}{c}{ Std. Deviation } \\
\cline { 2 - 7 } & Statistic & Statistic & Statistic & Statistic & Std. Error & Statistic \\
\hline Reliability & 297 & 1.25 & 5.00 & 3.2085 & .04622 & .79649 \\
\hline Assurance & 297 & 1.33 & 5.00 & 3.2612 & .04662 & .80335 \\
\hline Responsiveness & 297 & 1.00 & 5.00 & 3.0438 & .04606 & .79386 \\
\hline Empathy & 297 & 1.17 & 5.00 & 3.3189 & .04975 & .85742 \\
\hline Tangible & 294 & 1.67 & 5.00 & 3.2460 & .04229 & .72507 \\
\hline Overall satisfaction & 297 & 1.93 & 5.00 & 3.2172 & .03735 & .64369 \\
\hline
\end{tabular}


The table 08 represents the mean values for each items of reliability variable. Only $55 \%$ patient were satisfied with informing the investigation results correctly. It was below their expectations. On the other hand, $40 \%$ of the patients were not satisfied for providing adequate information prior to investigations. However, $90 \%$ of them claimed that they were satisfied just as they expected or more than expected for receiving medication on time.

Table 08: Satisfaction with reliability according to SERVQUAL

\begin{tabular}{llllll}
\hline Items of reliability & $\mathrm{N}$ & Min. & Max. Mean & SD \\
\hline Informing me reports & 287 & 1 & 5 & 2.52 & 1.211 \\
\hline Observing me well frequently & 295 & 1 & 5 & 3.46 & 1.099 \\
\hline Explaining a relevant situation simply & 297 & 1 & 5 & 3.49 & 1.010 \\
\hline Giving me care and medication on time & 292 & 1 & 5 & 3.32 & .837 \\
\hline Providing adequate information prior to investigations & 291 & 1 & 5 & 2.82 & 1.257 \\
\hline
\end{tabular}

Table 09 shows the means for each items of assurance. $80 \%$ of the patients were satisfied just as they expected or above for nurses' help in carrying out doctors' orders. For advising whenever necessary, nearly $30 \%$ of the participants mentioned that it was much less or less than they expected. $75 \%$ were stated that their expectations were met with therapeutic touch and opportunity to share feelings.

Table 09: Patient satisfaction with assurance as measured with SERVQUAL

\begin{tabular}{llllll}
\hline Items of assurance & $\mathrm{N}$ & Min. & Max. & Mean & SD \\
\hline Opportunity to share my feelings & 294 & 1 & 5 & 3.17 & 1.053 \\
\hline Therapeutic touch & 283 & 1 & 5 & 3.35 & .926 \\
\hline Help in carrying out doctors' orders & 295 & 1 & 5 & 3.45 & .924 \\
\hline Advises me whenever necessary & 294 & 1 & 5 & 3.09 & 1.152 \\
\hline
\end{tabular}

Table 10 represents the mean value for items of responsiveness.80\% of the patients satisfied that their pain management was just as they expected or more than they expected. $30 \%$ of them expressed their dissatisfaction for not questioning to identify their need or spending insufficient time to answer their questions.

Table 10: Patient satisfaction with responsiveness as measured with SERVQUAL

\begin{tabular}{llllll}
\hline Items of responsiveness & N & Min. & Max. & Mean & SD \\
\hline Assist in reducing pain & 275 & 1 & 5 & 3.34 & .923 \\
\hline enough time to answer my questions & 295 & 1 & 5 & 2.93 & 1.059 \\
\hline Asking questions to clarify what I need & 289 & 1 & 5 & 2.88 & .967 \\
\hline
\end{tabular}

Table 11 shows the mean for items of empathy. $90 \%$ patients were satisfied about the nurses' quality of talking kindly and politely due to their expectations were met. $25 \%$ of them claimed encouragement given by the nurses to ask question and understanding their feeling were less or mush less than their satisfactory level. 
Table 11: Patient satisfaction with empathy as measured with SERVQUAL

\begin{tabular}{llllll}
\hline Items op empathy & $\mathrm{N}$ & Min. & Max. & Mean & SD \\
\hline Talking politely and kindly & 297 & 1 & 5 & 3.62 & 1.088 \\
\hline Being friendly & 297 & 1 & 5 & 3.55 & 1.061 \\
\hline Encouraging me to ask questions & 242 & 1 & 5 & 2.95 & 1.073 \\
\hline Explaining a relevant situation in a simple manner & 293 & 1 & 5 & 3.21 & .966 \\
\hline Understanding my feelings & 297 & 1 & 5 & 3.19 & 1.057 \\
\hline Respecting my suggestions/ opinions & 287 & 1 & 5 & 3.31 & .843 \\
\hline
\end{tabular}

Mean for items of tangible is illustrated by table 12. 80-95\% patients were satisfied about nurses' neat appearance, providing enough ventilation and nurses' actions for preparing ward environment neat and tidy.

Table 12: Satisfaction with tangible as measured with SERVQUAL

\begin{tabular}{llllll}
\hline Items of tangible & $\mathrm{N}$ & Min. & Max. & Mean & SD \\
\hline Being neat in nurses' appearance & 294 & 1 & 5 & 3.28 & .723 \\
\hline $\begin{array}{l}\text { Taking actions for preparing my environment } \\
\text { neat and tidy }\end{array}$ & 292 & 1 & 5 & 3.28 & 1.120 \\
\hline \begin{tabular}{l} 
Providing required ventilation \\
\hline
\end{tabular} & 294 & 1 & 5 & 3.18 & .759 \\
\hline
\end{tabular}

Table 13: Pearson Correlation between mean PCB (patient) and modified SERVQUAL

\begin{tabular}{llll}
\hline \multirow{2}{*}{ mean_PCB_patient } & \multicolumn{1}{l}{ Pearson Correlation } & 1 & mean_SERVQUAL \\
\cline { 2 - 4 } & \multicolumn{2}{l}{ Sig. (2-tailed) } & $.657^{* *}$ \\
\cline { 2 - 4 } & $\mathrm{N}$ & 300 & 300 \\
\hline mean_SERVQUAL & Pearson Correlation & $.657^{* *}$ & 1 \\
\cline { 2 - 3 } & Sig. (2-tailed) & .000 & 300 \\
\cline { 2 - 3 } & $\mathrm{N}$ & 300 & 300 \\
\hline$* *$ Correlation is significant at the 0.01 level (2-tailed).
\end{tabular}

**. Correlation is significant at the 0.01 level (2-tailed).

Pearson's R for the correlation between patients' perception of caring behaviour and satisfaction on expected quality is 0.66 (table 13). As it is more than 0.6, there is a strong relationship. Sig. (2-Tailed) value is $0.00<0.05$ (table 13). Hence, it can be concluded that there was a statistically significant relationship between patients' perception of nurses' caring behaviour and patient satisfaction with nursing care. Scatterplots showed a linear trend between the independent variable and the dependent variable since data are distributed on either side of the line (figure 1).The table 14 summarized the correlation between patient satisfaction on expected care (overall means on SERVEQUAL) and each variables of patients' perception on nurses caring behaviours. The chart illustrated that there were strong correlations between satisfaction and each variables of nurses' caring behaviours $(\mathrm{p}$ value $=0.00<0.05)$. 


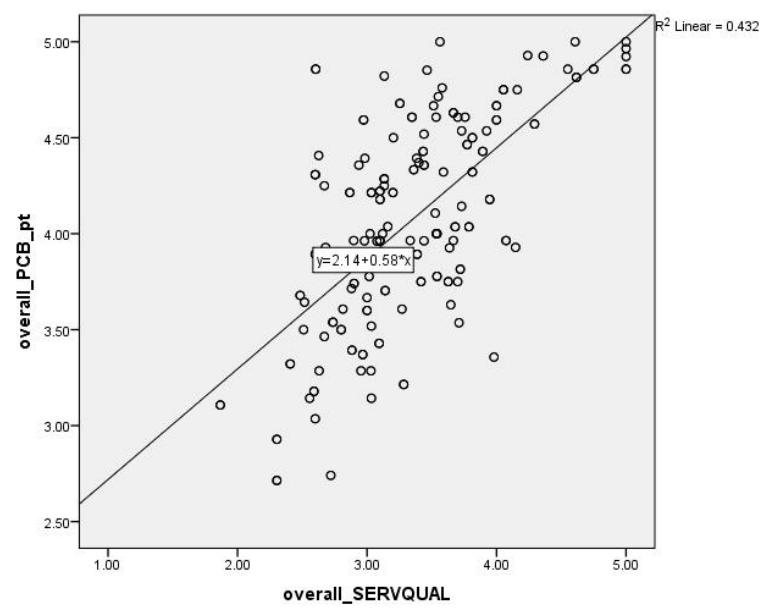

Figure 1: Scatterplots showed the independent variables $(P C B)$ and the dependent variable (modified SERVQUAL)

Table 14: relationship between patient satisfaction on expected care (overall means on SERVEQUAL) and each variables of patients' perception on nurses' caring behaviour

\begin{tabular}{|c|c|c|c|c|c|c|}
\hline & & $\begin{array}{l}\text { mean_- } \\
\text { SERVQUAL }\end{array}$ & $\begin{array}{l}\text { Professionalis } \\
\mathrm{m}\end{array}$ & $\begin{array}{l}\text { Assuranc } \\
\text { e }\end{array}$ & $\begin{array}{l}\text { Relationshi } \\
\mathrm{p}\end{array}$ & $\begin{array}{l}\text { Knowledge } \\
\text { \&skill }\end{array}$ \\
\hline \multirow{4}{*}{$\begin{array}{l}\text { mean_- } \\
\text { SERVQUAL }\end{array}$} & Pearson & 1 & $.550 * *$ & $.507 * *$ & $.563 * *$ & $.591 * *$ \\
\hline & Correlation & & & & & \\
\hline & $\begin{array}{l}\text { Sig. (2- } \\
\text { tailed) }\end{array}$ & & .000 & .000 & .000 & .000 \\
\hline & $\mathrm{N}$ & 300 & 300 & 300 & 300 & 300 \\
\hline \multirow[t]{3}{*}{$\begin{array}{l}\text { Professionalis } \\
\mathrm{m}\end{array}$} & $\begin{array}{l}\text { Pearson } \\
\text { Correlation }\end{array}$ & $.550 * *$ & 1 & $.572 * *$ & $.707 * *$ & $.688 * *$ \\
\hline & $\begin{array}{l}\text { Sig. (2- } \\
\text { tailed) }\end{array}$ & .000 & & .000 & .000 & .000 \\
\hline & $\mathrm{N}$ & 300 & 300 & 300 & 300 & 300 \\
\hline \multirow[t]{3}{*}{ Assurance } & $\begin{array}{l}\text { Pearson } \\
\text { Correlation }\end{array}$ & $.507 * *$ & $.572 * *$ & 1 & $.488 * *$ & $.589 * *$ \\
\hline & $\begin{array}{l}\text { Sig. (2- } \\
\text { tailed) }\end{array}$ & .000 & .000 & & .000 & .000 \\
\hline & $\mathrm{N}$ & 300 & 300 & 300 & 300 & 300 \\
\hline \multirow[t]{3}{*}{ Relationship } & $\begin{array}{l}\text { Pearson } \\
\text { Correlation }\end{array}$ & $.563 * *$ & $.707 * *$ & $.488 * *$ & 1 & $.580 * *$ \\
\hline & $\begin{array}{l}\text { Sig. (2- } \\
\text { tailed) }\end{array}$ & .000 & .000 & .000 & & .000 \\
\hline & $\mathrm{N}$ & 300 & 300 & 300 & 300 & 300 \\
\hline \multirow[t]{3}{*}{$\begin{array}{l}\text { Knowledge \& } \\
\text { Skill }\end{array}$} & $\begin{array}{l}\text { Pearson } \\
\text { Correlation }\end{array}$ & $.591 * *$ & $.688 * *$ & $.589 * *$ & $.580 * *$ & 1 \\
\hline & $\begin{array}{l}\text { Sig. (2- } \\
\text { tailed) }\end{array}$ & .000 & .000 & .000 & .000 & \\
\hline & $\mathrm{N}$ & 300 & 300 & 300 & 300 & 300 \\
\hline
\end{tabular}


Regression analysis was conducted to predict a model. Significant value from ANOVA test (p-value) is $0.00 \leq$ 0.05 (table 16). R2 (coefficient of determination) is 0.444 (table 15). Therefore, about $44.4 \%$ of the variation in the satisfaction on expected nursing care is explained by perception on caring behaviors of nurses. Figure 2 represents the scatterplot chart for multiple regression analysis. It showed that data points line together to make a normal p-p plot which indicating the residuals were normally distributed. Then, it was a good model for this data set. Coefficients table (table 17) represented each components of independent variable (nurses' caring behaviour variables)

Table 15: model summary of independent variable (patients' perception on nurses' caring behaviours through $P C B)$ and dependent variable (satisfaction of expected care through modified SERVQUAL)

\begin{tabular}{lllll}
\multicolumn{2}{l}{ Model Summary } & & \\
Model & R & R Square & Adjusted R Square & Std. Error of the Estimate \\
\hline 1 & $.666 \mathrm{a}$ & .444 & .436 & .46580 \\
\hline
\end{tabular}

a. Predictors: (Constant), knowledge \& skill, relationship, assurance, professionalism

Table 16: ANOVA chart showing the significance of the relationship between dependent and independent variable

ANOVAa

\begin{tabular}{lllllll} 
Model & & Sum of Squares & df & Mean Square & F & Sig. \\
\hline \multirow{2}{*}{1} & Regression & 51.092 & 4 & 12.773 & 58.870 & $.000 \mathrm{~b}$ \\
\cline { 2 - 6 } & Residual & 64.005 & 295 & .217 & \\
\cline { 2 - 6 } & Total & 115.097 & 299 & & \\
\hline
\end{tabular}

Table 17: Coefficients table representing each components of independent variable

\begin{tabular}{|c|c|c|c|c|c|c|}
\hline \multicolumn{7}{|c|}{ Coefficientsa } \\
\hline \multirow[b]{2}{*}{ Model } & & \multicolumn{2}{|c|}{ Unstandardized Coefficients } & \multirow{2}{*}{$\begin{array}{l}\text { Standardized Coefficients } \\
\text { Beta }\end{array}$} & \multirow[b]{2}{*}{$\mathrm{t}$} & \multirow[b]{2}{*}{ Sig. } \\
\hline & & $\mathrm{B}$ & Std. Error & & & \\
\hline \multirow[t]{5}{*}{1} & (Constant) & .302 & .211 & & 1.430 & .154 \\
\hline & Professionalism & .059 & .067 & .063 & .880 & .380 \\
\hline & Assurance & .164 & .055 & .168 & 2.977 & .003 \\
\hline & Relationship & .275 & .065 & .266 & 4.252 & .000 \\
\hline & Knowledge \& skill & .251 & .055 & .295 & 4.606 & .000 \\
\hline
\end{tabular}

a. Dependent Variable: mean_SERVQUAL 


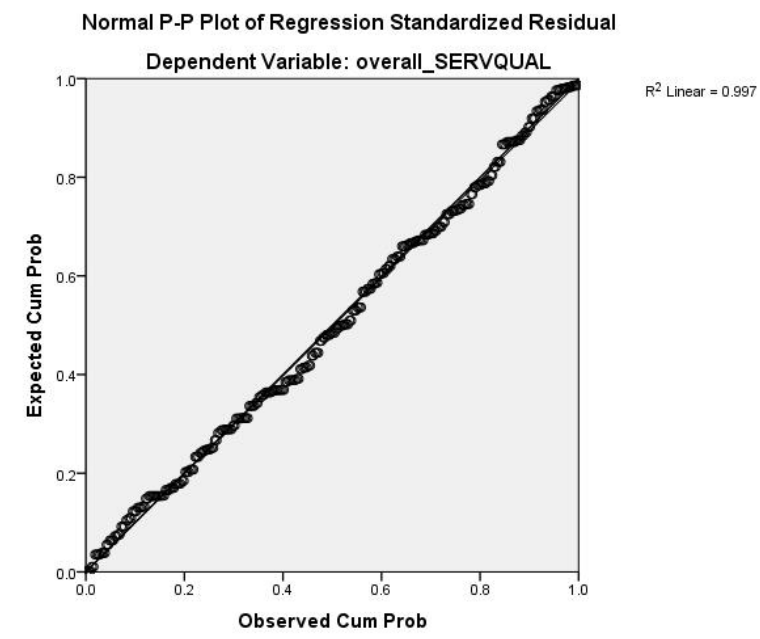

Figure 2: Scatter plot for multiple regression analysis

Student nurses perception was measured by the student version of questionnaire used for the patients, "Perception of Caring Behaviors (PCB)". Higher score (ranging from 1 to 5) reflects greater nurse caring behaviors as rated by the student nurses. Mean perception of student nurses was $3.47 \pm 0.65$. Student nurses perception is shown in table 18 .

Table 18: Student nurses perception on nurses' caring behaviors - Descriptive Statistics of each variables of PCB-student version

\begin{tabular}{llllll}
\hline Variables of PCB- student version & $\mathrm{N}$ & Min. & Max. & Mean & SD \\
\hline Professionalism & 115 & 2.00 & 5.00 & 3.6758 & .68154 \\
\hline Assurance & 115 & .00 & 5.00 & 3.2467 & .77965 \\
\hline Relationship & 115 & .50 & 5.00 & 3.3272 & .80646 \\
\hline Knowledge \& skill & 115 & .00 & 5.00 & 3.6661 & .86804 \\
\hline Overall & 115 & 1.13 & 4.95 & 3.4789 & .65896 \\
\hline
\end{tabular}

Student nurses' perception of the care delivered by the staff nurses was lower than patients' perception with all the four variable as well as with overall perception as displayed by Table 19.

Table 19: Difference between perception on nurses caring behaviour among patients and student nurses

\begin{tabular}{|c|c|c|c|c|c|}
\hline Variable & type & $\mathrm{N}$ & Mean & $\mathrm{SD}$ & Std. Error Mean \\
\hline \multirow[t]{2}{*}{ professionalism } & patient & 300 & 4.0019 & .64873 & .03745 \\
\hline & student & 115 & 3.6758 & .68154 & .06355 \\
\hline \multirow[t]{2}{*}{ Assurance } & patient & 300 & 4.0067 & .66495 & .03839 \\
\hline & student & 115 & 3.2467 & .77965 & .07270 \\
\hline \multirow[t]{2}{*}{ Relationship } & patient & 300 & 4.0704 & .61398 & .03545 \\
\hline & student & 115 & 3.3272 & .80646 & .07520 \\
\hline \multirow[t]{2}{*}{ Knowledge \& skill } & patient & 300 & 3.9213 & .74883 & .04323 \\
\hline & student & 115 & 3.6661 & .86804 & .08094 \\
\hline \multirow[t]{2}{*}{ Mean perception } & patient & 300 & 4.0240 & .54003 & .03118 \\
\hline & student & 115 & 3.4519 & .65880 & .06143 \\
\hline
\end{tabular}


As illustrates in table 20, independent t-test, show a significance difference between patients' and student nurses' perception of overall (mean) nursing care $(\mathrm{p}=0.038<0.05)$. When considering individual variables, only the assurance and relationships showed the significance deference between the responses given by student nurses and patients. ( $\mathrm{p}=0.036<0.05$ and $0.004<0.05$, respectively). However, there was no significance difference on perception between patients and student nurses on professionalism $($ sig. $=0.906>0.05)$ and on Knowledge-skill (significance value is $0.398>0.05$ ).

Table 20: independent T- test (patients' and student nurses' perception on nursing care delivered by staff nurses)

\begin{tabular}{|c|c|c|c|c|c|c|c|c|c|}
\hline \multicolumn{10}{|c|}{ Independent Samples Test } \\
\hline & & \multicolumn{8}{|c|}{$\begin{array}{l}\text { Levene's Test } \\
\text { for Equality of } \\
\text { Variances t-test for Equality of Means }\end{array}$} \\
\hline & & \multirow[b]{2}{*}{$\mathrm{F}$} & \multirow[b]{2}{*}{ Sig. } & \multirow[b]{2}{*}{$\mathrm{t}$} & \multirow[b]{2}{*}{ df } & \multirow{2}{*}{$\begin{array}{l}\text { Sig. (2 } \\
\text { tailed) }\end{array}$} & \multirow{2}{*}{$\begin{array}{l}\text {-Mean } \\
\text { Difference }\end{array}$} & \multirow{2}{*}{$\begin{array}{l}\text { Std. Error } \\
\text { Difference }\end{array}$} & $\begin{array}{l}95 \% \\
\text { Confidence } \\
\text { Interval of the } \\
\text { Difference } \\
\end{array}$ \\
\hline & & & & & & & & & Lower Upper \\
\hline \multirow[t]{2}{*}{ Professionalism } & $\begin{array}{l}\text { Equal } \\
\text { variances } \\
\text { assumed }\end{array}$ & .014 & .906 & 4.519 & 413 & .000 & .32613 & .07216 & .18428 .46798 \\
\hline & $\begin{array}{l}\text { Equal } \\
\text { variances } \\
\text { not } \\
\text { assumed }\end{array}$ & & & 4.421 & $\begin{array}{l}197.8 \\
42\end{array}$ & .000 & .32613 & .07377 & . 18065.47160 \\
\hline \multirow[t]{2}{*}{ Assurance } & $\begin{array}{l}\text { Equal } \\
\text { variances } \\
\text { assumed }\end{array}$ & 4.446 & .036 & 9.920 & 413 & .000 & .75993 & .07661 & .60934 .91052 \\
\hline & $\begin{array}{l}\text { Equal } \\
\text { variances } \\
\text { not } \\
\text { assumed }\end{array}$ & & & 9.243 & $\begin{array}{l}181.0 \\
71\end{array}$ & .000 & .75993 & .08222 & $.59770 \quad 92215$ \\
\hline \multirow[t]{2}{*}{ Relationship } & $\begin{array}{l}\text { Equal } \\
\text { variances } \\
\text { assumed }\end{array}$ & 8.461 & .004 & 10.075 & 413 & .000 & .74324 & .07377 & .59823 .88826 \\
\hline & $\begin{array}{l}\text { Equal } \\
\text { variances } \\
\text { not } \\
\text { assumed }\end{array}$ & & & 8.940 & $\begin{array}{l}167.1 \\
41\end{array}$ & .000 & .74324 & .08314 & .57911 .90738 \\
\hline \multirow[t]{2}{*}{ Knowledge_skill } & $\begin{array}{l}\text { Equal } \\
\text { variances } \\
\text { assumed }\end{array}$ & .716 & .398 & 2.970 & 413 & .003 & .25525 & .08594 & .08632 .42418 \\
\hline & $\begin{array}{l}\text { Equal } \\
\text { variances } \\
\text { not } \\
\text { assumed }\end{array}$ & & & 2.781 & $\begin{array}{l}182.6 \\
53\end{array}$ & .006 & .25525 & .09177 & $\begin{array}{ll}.07419 .43631\end{array}$ \\
\hline \multirow[t]{2}{*}{ Mean perception } & $\begin{array}{l}\text { Equal } \\
\text { variances } \\
\text { assumed }\end{array}$ & 4.315 & .038 & 9.068 & 413 & .000 & .57215 & .06309 & .44812.69617 \\
\hline & $\begin{array}{l}\text { Equal } \\
\text { variances } \\
\text { not } \\
\text { assumed }\end{array}$ & & & 8.305 & $\begin{array}{l}175.8 \\
43\end{array}$ & .000 & .57215 & .06889 & 43619.70811 \\
\hline
\end{tabular}




\section{Discussion}

Reduction of patient satisfaction is a result of 'uncaring' nurses (Aiken et al., 2018). Patients of this study were rated lower values for information provided by the nurses prior to investigations. On the other hand, they stated that information provision was less than their expectations. However, several studies concluded the relationship between patient satisfaction and information provision. There was a clear association between the level of the quality of nursing care and the level of received knowledge (Leino-Kilpi et al., 2015).Integrative review of patients' satisfaction with the nursing care during hospitalization using 10 studies found that patient satisfaction was influenced by nurses' caring behavior when providing adequate information, and prompt response to patients' needs with technical and professional expertise (Goh and Vehvilainen-julkunen, 2016). Hence patient satisfaction can be improved through bedside handover which facilitates the patients' perceptions of accessible care, reliable care and it can increase patient participation (Mako, Svanang and Bjersa, 2016). Therapeutic touch meant the touching patient's arm or shoulder while providing nursing care or communication. Although $80 \%$ were stated that their expectations were met with therapeutic touch, only $32 \%$ patients perceived that nurses practiced therapeutic touch while caring or communication. The discrepancy may be raised due to cultural background and patients' unawareness on ideal nursing care. Nurses were friendly, talk kindly and administer medication on time. However, nurses should encourage the patients to raise the questions to clarify their needs and problems. Nurses need to understand patients' feelings more. Hence, emphatic approach is essential. Information provision prior to investigations/examinations and informing investigation/examination results (such as vital signs, hemoglobin level) should practice more to meet patient's expectations.

In this study the patients exhibited higher rate for overall satisfaction with nursing care. A similar study concluded in India, and found that satisfaction of patient with quality of nursing care in Neuro-medical and general medical ward was above the level of average (Varghese, 2009). Level of satisfaction among patients in current study was above average level for tangible, reliability, responsiveness, empathy and assurance. In contrast, in the study of Saudi Arabia found that patients were not satisfied with the nursing service quality in relation to all dimensions of SERVEQUAL (Al-Momani, 2016).A research from Ghana found that overall satisfaction of patients concerning the service quality of the hospital was good although patients were not satisfied with the four dimensions of service quality such as Reliability, Communication/interpersonal relationship, Assurance, and Responsiveness. On the contrary, Tangibility and Empathy dimensions scored positive which supports patients' impression about the service in a study conducted by Peprah and Atarah (2014).According to their study patients of the Asian countries might be satisfied easily as their expectations were low.

According to the present study, there was a significant positive correlation between the patient perception of nurses' caring behaviors and satisfaction on quality of nursing care, although gap cannot be compered due to different scales used. Similar results were found in literature. Patient satisfaction was relevant to the nurses caring behaviors (Azizi-fini et al., 2012). A mix method study done in United States' found that there was a moderate relationship between patients' expectations and satisfaction (Reck, 2010). A study conducted in Australia concluded that "knowledgeable and communicable staff", 'timeliness of assistance" and "environmental support" were most significantly related to patient-perceived nursing care quality (Edvardsson, Watt and Pearce, 2017). According to their findings patient satisfaction can be predicted by the patients' perception of caring behaviour $(\mathrm{R} 2=0.44)$.If $\mathrm{R}$ Square is near to 1 or more than 0.7 , it is a best model to predict patients' satisfaction. However, some fields that attempts to predict human behavior such as psychology, expected R-squared values could be low (less than 50\%) due to humans are simply harder to predict than physical processes (Minitab Blog Editor, no date).Caring behaviours that is visible can be observed to understand the patient satisfaction in surgical-medical wards. As education for nurses has to emphasize attitudes needed to provide loving, compassionate care (Bagnall, 2017), curriculum changes based on Jean Watson's theory on caring will improve the caring behaviours. 
Mean value for student nurses' overall perception was lower than the patients'. Patient, as lay persons, may not fully aware of the caring behaviors of the nurses. It may be the reason to increase the patient satisfaction in this study. Similar study was conducted in Nairobi with Jean Watson's theoretical influence(Muhoro, 2012). The study results showed that students rated highly the subscales of anticipates, and monitors and follows through. In the same study the patients rated highly the subscales of anticipates, accessible, and comforts as well. In the current study showed that all the subscale were highly rated by the Sri Lankan patients than student nurses. On the one hand, demonstration of caring behaviors by clinical nurses can be a key factor in influencing the learners' perception of the importance of caring behaviors in the profession (Atwood, 2017). Improvement of public awareness on nursing care will be beneficial to improve quality nursing care.

Jean Watson also mentioned that assisting with the basic need is sacred act (Caring Science Theory | Watson Caring Science Institute, no date).On contrary, there are non-clinical features of the hospital that influence patient satisfaction; such as admission process, meals and room accommodations (Gares, 2011). Another study has been concluded that, nurse outcome which indirectly improves patient satisfaction is depended on several factors such as nurse staffing, work environment and hospital characteristics (Kelly, McHugh and Aiken, 2012). Further study is recommended to explore mediating factors of patient satisfaction other than nursing care.

\section{Conclusion}

Caring relationship is the core of professional nursing. Perception on caring behavior and patient satisfaction on nursing service quality were above average level. There is a strong correlationship between perceived caring behaviour and patient satisfaction with nursing care. Satisfaction on nursing care is explained by perception on nursing caring behaviors. Finding suggests that patients rated themselves higher in terms of caring behavior as compared to the ratings of student nurses. Two caring behaviors, assurance and relationships showed the significance deference with student nurses and patients. There was no significance difference on perception of professionalism and knowledge-skill between two groups. Incorporating the Jean Watson's theory on caring will improve the patient satisfaction on nursing care.

\section{Recommendations}

The cultural appropriateness and need for applying therapeutic touch while caring is recommended as there is discrepancy between perception of practice and expectation. Bedside handover is recommended to increase patients' perception on caring behaviors. Findings from this research are recommended to reform policies in the hospitals to improve the patient experience, to improve the nursing practice and to revise the curriculum in basic nursing education. Continuous nursing education while practice is also recommended. Further researches can be carried out to compere the perception between the nurses' and patients' perception on service quality of the nursing care. Various type of stakeholders can be taken into the research such as medical officers, family members and family care givers. Patient satisfaction with nursing care should be explored qualitatively as well. Similar study can be carried out in other units, non-teaching hospitals and other provinces. Incorporate Jean Watson's theory based nursing care is recommended to improve research on this area.

\section{Limitations of the Study}

This study did not pay attention for mediating effects of patient satisfaction. The data was collected while the patients were in the hospital as an interviewer assisted data collection which may affect the results. It would be better to identify the difference perception between caregiver and receiver. 


\section{Dissemination of information:}

The findings will be disseminated in the form of abstracts submitted for the scientific session, journal articles and presentations. The results will be of great benefit to nurse administrators and educators for enhancing patient satisfaction.

\section{References}

Aiken, L. H. et al. (2018) 'Patient satisfaction with hospital care and nurses in England: An observational study', BMJ Open, 8(1), pp. 1-8. doi: 10.1136/bmjopen-2017-019189.

Atwood, A. G. (2017) A comparative examination of nursing student perceptions of caring behaviors demonstrated by clinical faculty in associate degree and baccalaureate degree nursing. Capella University. Available at: Retrieved from ProQuest Education Juornal database (OUM Digital Collection).

Azizi-fini, I. et al. (2012) 'Correlation between nurses' caring behaviors and patients' satisfaction', Nursing and Midwifery Studies, 1(1), pp. 36-40. doi: 10.5812/nms.7901.

Bagnall, L. A. (2017) A quantitative analysis of BSN and ASN nursing students ' caring attributes. University of Phoenix. Available at: Retrieved from ProQuest Education Juornal database (OUM Digital Collection).

Bicknell, P. A. (2008) 'Nurses' perceptions of patient-centered care delivery: A mixed methods analysis of factors influencing effective implementation of patient-centered care', (July). Available at: Retrieved from ProQuest Education Juornal database (OUM Digital Collection).

Bucco, T. (2015) Relationships between patient's perception of nurse caring behaviours, nurses' perception of nurse caring behaviors and patint satisfaction in the emergengy department. Available at: Retrieved from ProQuest Education Juornal database (OUM Digital Collection).

Caring Science Theory | Watson Caring Science Institute (no date). Available at: https://www.watsoncaringscience.org/jean-bio/caring-science-theory/ (Accessed: 4 March 2017).

Chan, H. S. et al. (2015) 'Effects of a care workshop on caring behaviors as measured by patients and patient satisfaction', Open Journal of Nursing, 5. doi: 10.4236/ojn.2015.52010.

Dayasiri, M. B. K. . and Lekamge, E. L. . (2010) 'Predictors of patient satisfaction with quality of health care in Asian hospitals', Australasian Medical Journal, 3(11), pp. 739-744. doi: 10.4066/AMJ.2010.375.

Feuerbach, R. D. (2007) An investigation of the relationship between patient preferences for dimensions of nursing care and patient satisfaction with nursing care. $\mathrm{N}$ ew York University. Available at: Retrieved from ProQuest Education Juornal database (OUM Digital Collection).

Gares, D. (2011) 'The relationship of acute inpatient hospital length of stay and patient satisfaction', pp. 1-159. Available at: Retrieved from ProQuest Education Juornal database (OUM Digital Collection).

Goh, M. L. and Vehvilainen-julkunen, K. (2016) 'Hospitalised patients' satisfaction with their nursing care : An integrative review', Singapore Nursing Journal, 43(2).

Kelly, L. A., McHugh, M. D. and Aiken, L. H. (2012) 'Nurse outcomes in Magnet and non-Magnet hospitals.', The Journal of nursing administration. NIH Public Access, 42(10 Suppl), pp. S44-9. doi: 10.1097/01.NNA.0000420394.18284.4f.

Leino-Kilpi, H. et al. (2015) 'Knowledge received by hospital patients-a factor connected with the patientcentred quality of nursing care', International Journal of Nursing Practice, 21(6), pp. 689-698. doi: 10.1111/ijn.12277.

Mako, T., Svanang, P. and Bjersa, K. (2016) 'Patients' perceptions of the meaning of good care in surgical care : a grounded theory study', BMC Nursing. BMC Nursing, pp. 1-9. doi: 10.1186/s12912-016-0168-0.

Mien Li GOH; Vehviläinen-julkunen, K. (2016) 'Hospitalised Patients' Satisfaction with Their Nursing Care: An Integrative Review', Singapore Nursing Journal, 43(2), pp. 11-27.

Milutinovic, D. et al. (2012) 'The patient satisfaction with nursing care quality: The psychometric study of the Serbian version of PSNCQ questionnaire', Scandinavian Journal of Caring Sciences, 26(3), pp. 598-606. doi: 10.1111/j.1471-6712.2012.00969.x. 
Minitab Blog Editor (no date) Regression analysis: How do I interpret R-squared and assess the goodness-offit?, 2013. Available at: http://blog.minitab.com/blog/adventures-in-statistics-2/regression-analysis-how-do-iinterpret-r-squared-and-assess-the-goodness-of-fit (Accessed: 17 June 2018).

Modic, M. B. et al. (2016) 'Caring behaviors: perceptions of acute- care nurses and hospitalized patients with diabetes. Descriptive correlational mixed-method research design', International Journal for Human Caring, 20(3), pp. 160-164. Available at: http://search.ebscohost.com/login.aspx?direct=true\&db=jlh\&AN=118464895\&site=ehost-live.

Mohebifar, R. et al. (2016) 'Evaluating service quality from patients' perceptions: application of importanceperformance analysis method', Osong public health and research perspectives. Korea Centers for Disease Control and Prevention, 7(4), pp. 233-8. doi: 10.1016/j.phrp.2016.05.002.

Muhoro, S. n. (2012) 'Perception of patients and student nurses on nursing care at Kenyatta National Hospital, medical wards.'

Mukumbang, F. C. and Adejumo, O. (2014) 'Patients' experiences of being nursed by student nurses at a teaching hospital', Curationis, 37(1), pp. 1-10. doi: 10.4102/curationis.v37i1.1230.

Peprah, A. A. and Atarah, B. A. (2014) 'Assessing patient' s satisfaction using SERVQUAL model : A case of Sunyani Regional Hospital, Ghana', International Journal of Business and Social Research, 4(2), pp. $133-143$.

Reck, D. L. H. (2010) Patients' expectations and satisfaction with nursing care, and their nurses' awareness of their expectations. The Pennsylvania State University. Available at: Retrieved from ProQuest Education Juornal database (OUM Digital Collection).

Senarat, U. and Gunawardena, N. S. (2011) 'Development of an instrument to measure patient perception of the quality of nursing care and related hospital services at the national hospital of Sri Lanka', Asian Nursing Research, 5(2), pp. 71-80. doi: 10.1016/S1976-1317(11)60015-7.

Varghese, J. (2009) A study to assess the patient satisfaction with quality nursing care in neuro medical unit, sctimst. Sree chitra tirunal institute of medical sciences and technology medical college, Trivandrum.

Wagner, D. and Bear, M. (2008) 'Patient satisfaction with nursing care: a concept analysis within a nursing framework', Journal of Advanced Nursing. doi: 10.1111/j.1365-2648.2008.04866.x.

Weathers, E. et al. (2012) 'Nurses ' caring behaviors in Ireland and the United States', International Journal for Human Caring, (2007), pp. 30-36. doi: 10.1188/15.CJON.352-360.

Youssef, H. . A. M. et al. (2013) 'A medical-surgical nurse's perceptions of caring behaviors among hospitals in Taif City Hanan’, Life Science Journal, 10(4), pp. 720-730. doi: 10(4):720-730. 